М.А. Яковлева

Mariya Yakovleva

\section{УПРАВЛЕНЧЕСКИЙ ПРОЦЕСС ВЗАИМОДЕЙСТВИЯ СТРУКТУР ПУБЛИЧНОЙ ВЛАСТИ И ГРАЖДАНСКОГО ОБЩЕСТВА}

Аннотация. В статье рассматривается взаимодействие гражданского общества со структурами публичной власти как управленческого прочесса. Исследуются основные формы воздействия в административно-политическом управлении в Российской Федерации и на основании этого определяются формь воздействия публичной власти на гражданское общество в рамках процесса управления. Представлены основные концепции и модели взаимодействия структур публичной власти и гражданского общества. Выявлено, что существует взаимодействие между гражданским обществом и структурами публичной власти, а также осуществляется взаимоуправление обеими структурами.

Ключевые слова: управление, гражданское общество, структуры публичной власти, управленческий проиесс, взаимодействие.

\title{
MANAGERIAL PROCESS OF INTERACTION OF THE STRUCTURES OF PUBLIC AUTHORITY AND CIVIL SOCIETY
}

Annotation. The article deals with the interaction of civil society with the structures of public authority as a managerial process. The main forms of influence in administrative and political governance in the Russian Federation are investigated and, on the basis of this, the forms of public authorities' influence on civil society are determined within the management process. Basic concepts and models of interaction between public authorities and civil society are presented. It was revealed that there is interaction between civil society and the structures of public authority, as well as mutual management of both structures.

Keywords: management, civil society, structures of public authority, managerial process, interaction.

Актуальность темы обусловлена тем, что изучение взаимодействия гражданского общества со структурами публичной власти важно для понимания развитости диалога государства с населением. В связи со становлением гражданского общества в России начинаются попытки налаживания устойчивого «диалога» между организациями, представляющими гражданское общество, и структурами публичной власти. В «диалоге» участвуют властные структуры, организации и объединения, которые представляют некоммерческий неправительственный сектор, «третий сектор».

Данная проблематика является одной из основных тем изучения в социологических исследованиях. При анализе уровне развития гражданского общества важным критерием является возможность или невозможность взаимодействия между этими двумя секторами. Под взаимодействием гражданского общества со структурами публичной власти в социальной сфере понимаются все разновидности социально-активного взаимодействия в сферах, не относящихся к политическим.

В процессе взаимодействия с населением гражданское общество и публичная власть используют различные методы, представляя собственные интересы и преследуя свои цели. Таким образом, исследование их диалога с точки зрения управленческого процесса является необходимым.

Одним из основных показателей эффективности и развитости института гражданского общества является наличие «третьего сектора» как представителя гражданского общества. Под «третьим

(C) Яковлева М.А. 
сектором» обычно понимают организации, занимающиеся некоммерческой негосударственной деятельностью, что противопоставляет их государственным и коммерческим структурам.

В источниках, посвященных проблеме становления и развития гражданского общества, а также его взаимодействию со структурами публичной власти, различают анализ личных гражданских инициатив и развития некоммерческого неправительственного сектора [1].

К личным гражданским инициативам относится степень вовлеченности граждан, активность их участия и гражданские инициативы. В данном процессе взаимодействия важно не только участие граждан в различных гражданских инициативах, но и новые возможности и сферы реализации гражданской вовлеченности в социальную и политическую сферы.

Во взаимодействии с некоммерческими организациями (далее - НКО) структуры публичной власти придерживаются двух точек зрения. Основным направлением деятельности структур является налаживание контакта публичной власти и гражданского общества. Структуры стремятся выделить потенциально лояльные, «политически ориентированные» НКО, с которыми государству возможно установить сотрудничество через структуры публичной власти и в дальнейшем частично объединиться, а также взять управление над частью деятельности НКО. Та часть НКО, которая определена как нелояльная по отношению к деятельности государства, представляется как оппозиционная и лишается возможности государственной поддержки. Следовательно, можно говорить, что НКО, работающие в политической сфере, классифицируются по принципу лояльного или оппозиционного отношения к государственной власти. Поэтому в некоторых НКО государство видит политических противников, что приводит к конфронтации. Те НКО, которые работают преимущественно в социальной сфере, получают дополнительные возможности для своей деятельности, создаются реестры социально ориентированных НКО [1].

При рассмотрении управленческого процесса взаимодействия структур публичной власти и гражданского общества следует описать положение этих субъектов, а также особенности их деятельности.

Согласно результатам исследований, проведенных «Левада-Центром» в 2015 г., можно отметить слабую вовлеченность отдельных граждан в политические и социальные процессы в стране, хотя прослеживается потенциальное увеличение внимания граждан к данной сфере [4]. Анализируя полученные данные, можно отметить, что 80 \% россиян не участвовали в деятельности общественных организаций, объединений, союзов, ассоциаций, товариществ, кооперативов, инициативных групп. Согласно полученным результатам, $50 \%$ опрошенных не участвовали ни в каких видах общественно активной жизни, а большинство участвовавших ограничивались участием в выборах и обсуждением с друзьями политических событий в стране. Активное участие в общественной жизни проявили 1-2 \% опрошенных, это проявилось в их участии в демонстрациях, митингах, протестах, забастовках.

Система взаимодействия между НКО и структурами публичной власти пока не отработана. На данный момент не существует общей методики оценки эффективности программ НКО, в том числе и тех, которые реализуются на средства государственных структур, что затрудняет процесс управления. Оценка эффективности в значительной степени зависит от опыта и возможностей тех структур, которые производят оценку, а также от предпочтений финансирующего органа. Как отмечают М. Н. Громова и И. В. Мерсиянова, «оценка эффективности в программах поддержки некоммерческих организаций, как правило, осуществляется на уровне отдельных профинансированных в рамках программы проектов, но не на уровне программы в целом» [2, с. 43].

В последние годы процесс взаимодействия гражданского общества и структур публичной власти можно охарактеризовать как слабо организованный со стороны обоих субъектов взаимодействия, но с положительной тенденцией в организации процесса взаимодействия. И, несмотря на наличие проблем, описанных выше, развитие взаимодействия субъектов достаточно перспективно. 
Во взаимодействии государства с «третьим сектором» происходит переход от конфронтации к попыткам наладить диалог различными способами. Среди подобных способов можно выделить увеличение финансирования государством НКО, создание объединений общественно-политических организаций и т.д.

Кроме того, среди новых тенденций в процессе управления и развитии взаимоотношений структур публичной власти с гражданским обществом можно отметить появление обратной связи. Это связано с тем, что некоммерческие организации исполняют различные «социальные заказы», которые предоставляет и финансирует не только государство. Некоммерческие организации управляются не только структурами публичной власти посредством финансирования выгодных для себя проектов. Теперь и сами организации «третьего сектора» имеют определенное влияние, регулируют деятельность властных структур. Становится возможным инициирование и продвижение через объединение с политическими организациями законопроектов, влияние на формирование цен ЖКХ и на закупки государственных организаций $[6 ; 7 ; 8]$.

Следовательно, в рамках управленческого процесса можно говорить о возможных перспективах во взаимодействии структур публичной власти с гражданским обществом. Например, государство может увеличить влияние на «третий сектор» посредством финансовой зависимости некоммерческих организаций от государства, создания все больше НКО и предпочтения коалиций «сверху» при ответе на запросы.

Стоит отметить другую возможность для развития иного варианта взаимодействия между субъектами, это консолидация и самоорганизация НКО в ряде регионов. Влияние государства на деятельность НКО может уменьшиться, это будет новым этапом в развитии гражданского общества. Кроме того, НКО могут стать независимыми от финансирования «социальных заказов» государства и оказать более сильное влияние на само государство через структуры публичной власти.

Как одно из перспективных направлений взаимодействия можно выделить деятельность в Молодежных палатах. Молодежный парламентаризм - это явление, считающееся элементом гражданского общества, обеспечивающее контакт между «третьим сектором» и государством. Молодежные палаты позволяют молодежи страны реализовывать активную социополитическую деятельность в сфере управления.

В РФ молодежное парламентское движение образовано в единое движение с общим информационным порталом [5]. Данное движение существует на федеральном, окружном, региональном и муниципальном уровнях. Каждый уровень представлен своей палатой и подчиняется более высокому уровню организации. Благодаря такой структуре можно решать и проблемы «верхнего» уровня, и более локальные проблемы, что делается, в частности, при помощи образованного Общероссийского Народного Фронта (далее - ОНФ).

Особенностью данного движения является первоочередная вовлеченность молодежи - активной части населения. Концепция реализации данного движения имеет перспективы, именно эта возрастная группа наиболее активно участвует в жизни регионов и страны в целом.

Другим перспективным направлением управленческого процесса является Общественная палата Российской Федерации. Эффективное взаимодействие гражданского общества и структур публичной власти через данную организацию вполне возможно.

Хотя Общественная палата работает не так активно в данный период, как ОНФ или Молодежные парламенты, наладить ее деятельность возможно при правильно выбранном направлении. Общественная палата призвана исполнять роль консалтингового и совещательного органа, приближенного больше к гражданам, тем не менее, степень доверия со стороны граждан достаточно низка. Согласно данным проведенного Фондом общественное мнение исследования, было выявлено, что 40 \% участников опроса не имеют представления о существовании палаты в целом, и лишь около 3 \% оценивают ее работу положительно [9]. Результаты исследования, проведенного «Левада-Центром», свидетельствуют о незначительной роли Общественной палаты в жизни населения на данный момент [3]. Менее 32 \% опрошенных знают о существовании палаты, и только 11 \% согласны с тем, что она играет важную политическую роль. 
Тем не менее, говорить о полной несостоятельности данной структуры как дискуссионной площадки между структурами публичной власти и гражданским обществом нельзя. Результаты деятельности ОНФ и Молодежных палат на всех уровнях свидетельствуют об определенных переменах в курсе государства относительно «третьего сектора», попытках построения диалога на равных и управления в двустороннем порядке. Несмотря на критические замечания, со стороны государственного управления уменьшается влияние на деятельность структур гражданского общества, сокращаются попытки манипулирования деятельностью НКО в стране. Следовательно, можно говорить о возможностях трансформации Общественной палаты для увеличения гибкости системы в целом и упрощения процесса управления в частности.

Также, говоря о процессе управления, стоит еще раз подчеркнуть, что увеличиваются перспективы большего управления со стороны структур публичной власти над гражданским обществом и наоборот. Общество в состоянии влиять на деятельность государства, контролировать ее, продвигать законы, добиваться изменений на всех уровнях через общественные движения, объединения, организации гражданского общество. В будущем деятельность в данном направлении должна продолжаться.

Таким образом, слабая заинтересованность граждан в социально-политической активности, несовершенство организации и управления НКО, их частичная фиктивность, с одной стороны, а с другой несовершенная система взаимодействия государства с «третьим сектором» являются основными проблемами взаимодействия гражданского общества со структурами публичной власти в Российской Федерации.

Стоит отметить, что существующие структуры гражданского общества представлены гражданами, которые в большинстве своем не заинтересованы в участии в социальных процессах государства. Также они представлены НКО, не все из которых занимаются реальной некоммерческой деятельностью, а могут организовываться для получения дотаций и пожертвований. Многие НКО занимаются социальной и политической деятельностью, имея слабо налаженную связь друг с другом, реализуя проекты самостоятельно. Они не могут осуществлять реализацию крупных проектов или обеспечивать обратную связь между определенными представителями групп населения.

Государство, в свою очередь, взаимодействует с данными структурами гражданского общества через структуры публичной власти. Государство проявляет интерес к «третьему сектору», преследует свои цели, увеличивая финансирование, следовательно, и влияние над организациями «третьего сектора».

Влияние выражается не только и не столько в запрете организаций и их деятельности. Влияние может проявляться во введении различных законодательств, регулирующих деятельность НКО, а также в образовании коалиций организаций под руководством государства. Государство выборочно поддерживает НКО, принимает законы, ограничивающие иностранное финансирование, что также является способами влияния и контроля.

В управленческом процессе взаимодействия структур публичной власти и гражданского общества можно отметить следующие особенности.

1. Развивающуюся социальную активность граждан.

2. Негласное разделение структур гражданского общества структурами публичной власти на «социально ориентированные» и «политически ориентированные».

3. Стремление государства контролировать «третий сектор», представленный, в первую очередь, НКО и увеличение финансирования.

4. Увеличение вовлеченности структур публичной власти во взаимодействии с гражданским обществом.

Несмотря на некоторые сложности, нельзя говорить о неработоспособности системы взаимодействия в целом. Наличие подобных проблем не говорит о неэффективности взаимодействия граж- 
данского общества со структурами публичной власти, а скорее о «незаконченности» становления системы данного управленческого процесса. Построение отношений между государством и «третьим сектором» находятся на стадии развития, что делает неизбежным возникновение проблем.

Кроме указанных проблем, можно отметить и положительные стороны во взаимодействии структур публичной власти и гражданского общества. Некоммерческие организации получают возможность реализовывать проекты, связанные с решением общественных и политических проблем страны. Под руководством государства создаются коалиции, позволяющие объединить различные направления общественно-политических организаций. В рамках гражданских инициатив отмечается подъем в заинтересованности и вовлеченности отдельных граждан в социально активную жизнь страны. Следовательно, становится возможным получение обратной связи, совместно реализация совместных проектов, требующих большого количества ресурсов.

В целом, управленческий процесс взаимодействия между гражданским обществом и структурами публичной власти находится в состоянии развития. Это постоянно изменяющийся процесс, который подстраивается под новые общественные реалии и совершенствуется, используя новые методы и отказываясь от уже неэффективных.

\section{Библиографический список}

1. Бардин, А.Л. Гражданское общество в России: опыт сравнительного анализа / А.Л. Бардин, А.Н. Кокарева, Е.В. Михайлова [Электронный ресурс]. - Режим доступа: http://www.civisbook.ru/files/File/CSM_2015.pdf (дата обращения: 25.11.2017).

2. Громова, М. Н. Государственная поддержка НКО и проблема оценки ее эффективности / М. Н. Громова, И. В. Мерсиянова // Гражданское общество в России и за рубежом. - 2016. - № 1. - С. 39-44.

3. Левада-Центр: деятельность Общественной палаты и Госдумы [Электронный ресурс]. -Режим доступа: http://www.levada.ru/2014/02/24/deyatelnost-obshhestvennoj-palaty-i-gosdumy (дата обращения: 25.11.2017).

4. Левада-Центр. Ежегодник «Общественное мнение» [Электронный ресурс]. - Режим доступа: http://www.levada.ru/sbornik-obshhestvennoe-mnenie/obshhestvennoe-mnenie-2015 (дата обращения: 25.11.2017).

5. Сайт Единого Молодежного Парламентского Движения [Электронный ресурс]. - Режим доступа: http://newparlament.ru (дата обращения: 27.11.2017).

6. Сайт Общероссийского Народного Фронта [Электронный ресурс]. - Режим доступа: http://onf.ru/2017/04/07/gosduma-prinyala-v-pervom-chtenii-zakonoproekt-onf-zashchishchayushchiy-smi-otshtrafov (дата обращения: 20.11.2017).

7. Сайт Общероссийского Народного Фронта [Электронный ресурс]. - Режим доступа: http://onf.ru/2016/08/12/blagodarya-onf-v-respublike-buryatiya-stoimost-elektroenergii-snizitsya-na-6 (дата обращения: 20.11.2017).

8. Сайт Общероссийского Народного Фронта [Электронный ресурс]. - Режим доступа: http://onf.ru/2016/05/13/eksperty-onf-v-sankt-peterburge-dobilis-priznaniya-narusheniy-pri-zakupkah-lenenergo-na (дата обращения: 20.11.2017).

9. Фонд Общественное мнение [Электронный ресурс]. - Режим доступа: http://fom.ru/Politika/10472 (дата обращения: 27.11. 2017).

\section{References}

1. Bardin A. L., Kokareva A. N., Mihajlova E. V. Grazhdanskoe obshchestvo v Rossii: opyt sravnitel'nogo analiza [Civil society in Russia: experience of comparative analysis]. Available at: http://www.civisbook.ru/files/File/CSM_2015.pdf (Accessed: 25 October 2017).

2. Gromova M. N., Mersiyanova I. V. Gosudarstvennaya podderzhka NKO i problema ocenki ee ehffektivnosti [State support of NPO and the problem of evaluation of its effectiveness]. Grazhdanskoe obshchestvo v Rossii i za rubezhom [Civil society in Russia and abroad], 2016, I. 1, pp. 39-44. 
3. Levada-Centr: deyatel'nost' Obshchestvennoj palaty i Gosdumy [The Levada Center: activities of the public chamber and the State Duma]. Available at: http://www.levada.ru/2014/02/24/deyatelnost-obshhestvennoj-palaty-i-gosdumy (Accessed 25 October 2017).

4. Levada-Centr. Ezhegodnik «Obshchestvennoe mnenie» [The Levada Center. Yearbook of the public opinion]. Available at: http://www.levada.ru/sbornik-obshhestvennoe-mnenie/obshhestvennoe-mnenie-2015 (Accessed: 25 October 2017).

5. Sajt Edinogo Molodezhnogo Parlamentskogo Dvizheniya [The website of Youth Parliamentary Movement]. Available at: http://newparlament.ru (Accessed: 27 November 2017).

6. Sajt Obshcherossijskogo Narodnogo Fronta [The website of the All-Russia People's Front]. Available at: http://onf.ru/2017/04/07/gosduma-prinyala-v-pervom-chtenii-zakonoproekt-onf-zashchishchayushchiy-smi-otshtrafov (Accessed: 20 October 2017).

7. Sajt Obshcherossijskogo Narodnogo Fronta [The website of the All-Russia People's Front]. - Available at: http://onf.ru/2016/08/12/blagodarya-onf-v-respublike-buryatiya-stoimost-elektroenergii-snizitsya-na-6 (Accessed: 27 November 2017).

8. Sajt Obshcherossijskogo Narodnogo Fronta [The website of the All-Russia People's Front]. Available at: http://onf.ru/2016/05/13/eksperty-onf-v-sankt-peterburge-dobilis-priznaniya-narusheniy-pri-zakupkah-lenenergo-na (Accessed: 27 November 2017).

9. Fond «Obshchestvennoe mnenie» [«The Public opinion» Foundation]. Available at: http://fom.ru/Politika/10472 (Accessed: 27 November 2017). 